\title{
A Research on Producer Reasons for Participation into Agricultural Fairs
}

\author{
Özdal Köksal ${ }^{1, a, *}$, Duygu Aktürk²,b, Sema Gün ${ }^{1, c}$ \\ ${ }^{1}$ Department of Agricultural Economics, Faculty of Agriculture, Ankara University, 06110 Ankara, Turkey \\ ${ }^{2}$ Department of Agricultural Economics, Faculty of Agriculture, Onsekiz Mart University, 17020 Çanakkale, Turkey \\ *Corresponding author \\ A R T I C L I N F O A B S T R A C T \\ Research Article \\ Ever-developing agricultural technologies and progress in communication science increase \\ competition and globalization in converge countries. Agricultural fairs offer ambient to bring \\ producers and input-suppliers of agriculture together at certain places and times. They offer direct \\ and efficient information about new technologies to producers. German Agricultural Society and \\ Received : 08/10/2021 \\ Accepted : 07/11/2021 \\ Leader Farmer Association have jointly organized outdoor fairs in Turkey since 2010. Agriculture \\ Days Fair is one of the most important events among these jointly organized fairs. This study was \\ conducted to determine the reasons for producers' participation in these fairs held in 2015 and 2017 \\ and to determine the effects of socio-economic characteristics of the producers on their reasons for \\ participation in these fairs. A total of 589 questionnaires were made in this study (250 in May 2015 \\ Keywords: \\ Agricultural fairs \\ Producer preferences \\ Information sources \\ Producer organizations \\ CHAID analysis \\ fair and 339 in August 2017 fair). The same questionnaire forms were used in both years. CHAID \\ analysis technique was employed in analyzing data gathered from the producers. It was observed \\ that producers generally participated in agricultural fairs just for the excursion or spent time with \\ their families at weekends. However, it was also determined that the producers were informed about \\ the agricultural fairs by producer organizations and Leader Farmer Association participated in the \\ fairs to promote a new products or to give information about new technologies and inputs. It can be \\ suggested that beyond informing producers about the fairs, Leader Farmer Association formed \\ within the scope of Leader Farmer Project initiated with the support of German Agricultural Society \\ (DLG) should convey information about how important the fairs are in the acquaintance with \\ introducing new information and technologies.
}

\section{Introduction}

Fairs play a significant role in bringing producers and consumers together. Besides, participant organizations and fair visitors constitute the groups to be satisfied separately for long-term business success and sustainability of the activity. Fairs turn into successful activities as long as renovation and introductory needs of the organizations and learning and trial demands of the visitors are met. Participant organizations organize marketing activities to generate a demand, to find new customers, improve sales and ultimately increase their market shares. Additionally, fairs allow organizations to meet new customers, to develop a positive image, to assess the efficiency of the products, to conduct a market search, to discover new products, to gain technical knowledge about the competitors, to see certain products and companies and to find new intermediaries or distributors (Santos and Mendoça, 2014; Caber et al., 2016). Fairs are also significant marketing tools allowing sellers to introduce and test new products, to monitor competitors and to have personal contacts with the customers (Havlíková and Kolárová, 2015).

Agricultural fairs are the visual places in which renovations, developments and technologies in agriculture and food industry are exhibited. In other words, they are the places in which agricultural sector meets the producers. Although the primary target of the fairs is marketing and sales, they play a significant role in reaching sectoral research and development (R\&D). Although the origin of the agricultural fairs goes back to the $18^{\text {th }}$ century, several numbers of agricultural fairs organized every year and they have thousands of visitors each time, a number of studies investigating the potential effects of such fairs on visitors are quite limited (Larsen, 2017). Traditional efficiency of agricultural fairs in bringing the buyers and the sellers 
together decreased through the development of different agricultural marketing methods, rapid developments in urbanization and information technologies and thus visitor mass in fairs of developed countries turn from rural to urban population (Acharya and Lillywhite, 2016). The change in visitor profile then shaped the agricultural fairs upon different activities and expectations (Mitchell, 2007). Perception of agricultural fairs with a long history in different countries as inefficient and unnecessary heritage as compared to the other means of communication resulted in the organization of different arrangements with different contents and designs. Funfairs and exhibitions then turned into rural fairs in which natural life, agriculture and local foods are introduced and supported with amusement and leisure time activities. Amusement search of fair visitors and their desires to participate fairs just for excursion purposes are developed totally independent of marketing purposes of the fairs. In general, fair visitors participate into fairs just to escape from routine living conditions, to learn about new products, to develop themselves, to benefit from the sales and to be more social (Caber et al., 2016). These fairs also increase social mobility and contribute to local life (Barros et al., 2016). Local fairs offer places to both small and mid-size companies for direct introduction or sale of their products to targeted customers and allow local people to purchase local foods.

Information technology facilitates information transfer qualitatively and quantitatively. Development and diffusion of information technologies and media facilities converged the information and the users. The majority of farmers of the countries with developed agricultural sector using the internet to reach the information think that such information was better than the ones reached through traditional methods (Stricker et al., 2003). Although information technologies play a significant role in reaching information on agriculture, e-trade applications have a little share in technology purchase of the farmers (Stricker et al., 2003). For instance, in Germany, fair visitors with a real interest in technology and knowledge on the internet presented agricultural fairs among their information sources (Rosskopf and Wagner, 2005). Especially in countries where agricultural sector maintains demographic and economic significance, agricultural fairs still maintain their importance as a meeting ground in technology acquisition of agricultural producers just because of insufficient visibility of international markets and insufficient conditions of the farmers in reaching information.

Expectations of visitors from agricultural fairs and their reasons of visit may provide significant contributions to fair organizers. Therefore, shaping such fairs based on visitor demands and expectations will improve job success or sellers participating in these fairs. Agricultural fairs should think of consumer-oriented while presenting goods and services to visitors and they should know about the factors playing a role in their decision processes. The primary factor to be considered is to offer or design marketing programs providing consumer satisfaction. In this way, fair can be kept alive and better success can be achieved than the other marketing canals. Through reaching greater number of visitors and consumers, they will have higher reorganization probabilities.
Agricultural fairs are organized either for sales and publicity or for both. Bringing the companies providing inputs to agricultural sector and using the sector outputs together may offer significant opportunities in gaining more information about competitor activities of the sector, in identifying consumer behaviors and tendencies. Therefore, participants use fairs as a strong and effective marketing tool for company introduction, direct sale of goods and services or for finding new business partners. Since there is a chance for quick comparison of goods and services in fairs, visitors, buyers and exhibitor firms are in intense interactions and such interactions may then provide great contributions to development of agricultural sector. Such interactions also allow oral interactions of buyers who haven't had a previous chance for direct contact with the seller firms and may allow them to see how the price of the goods and services, which were previously thought to be high or unavailable, were quite available (Dwyer and Tanner, 1999). Fairs are also the places in which the goods and services are presented for the first time, in which visitors can see and test them and buy them from quite available prices since the sales are direct sales in fairgrounds (Ivkov et al., 2015). Fairs allow the buyer to examine the products before to decide, to gather information for their future purchases and to provide an ambient for sale of goods and services. Gaining information about new products and meeting with expert stuff are two important motivations attracting the attentions of the visitors. Therefore, organizers of such activities should always consider informing while creating new marketing strategies.

Agricultural fairs also visited by urbanite as a cultural or training activity in their spare times or to discover new activities with their friends and families. Such visitors mostly are not buyers or not interested in buying the goods and services. In this sense, agricultural fairs have a different function in creating rural and urban connection and in informing urbanite about production processes of foods.

It was hypothesized in this study that gaining knowledge and understanding of participation motivations of agricultural producer visitors of the fairs plays a key role in achieving their fair targets. Therefore, the primary objective of the present study was set as to ascertain producer characteristics.

\section{Methodology}

In 2015, 419 fairs were organized in Turkey and about 17 million people visited these fairs. Of these fairs, 64 (15\%) were about agriculture and greenhouse technologies and about 4.5 million people visited these fairs. In 2017 , 416 fairs were organized (53 were about agriculture and greenhouse technologies) and 18 million people visited these fairs (Anonymous, 2017).

One of these fairs has been held in different cities of Turkey since 2010 jointly by German Agricultural Society (DGL) and Leader Farmer Project (ÖÇP). In this study, the outdoor fairs of this joint operation were taken into consideration (the one held in Çanakkale province in 2015 with the participation of 138 companies over 47 thousand square meter outdoor space and another one held in Tekirdağ province in 2017 with the participation of 105 
companies over 120 thousand square meter outdoor space). There are two main reasons for selecting these fairs as the research material. The first: the fair was able to display agricultural products used in Turkey in a most innovative and professional fashion. The second: the fair was quite different from the others with respect to machine demos and product demonstrations. The fair had 26 thousand visitors in 2017 and 31 thousand visitors in 2015. All of these visitors were accepted as main universe of the study. The visitors under 18 years of age were left out of the scope. During 2015, the fair was held on 14-17 May and 250 questionnaires were made. During 2017, the fair was held on 23-26 August and 339 questionnaires were made (totally 589 questionnaires). The same questionnaire forms were used in 2015 and 2017.

In this study, CHAID (Chi-Square Automatic Interaction Detection) method was used since dependent variable of the present research is nominal categoric and independent variable is continuous categoric or nominal categoric (Doğan, 2003). CHAID analysis technique is a significant decision tree used to assess the factors influencing dependent variables and their level of significance. Thus, it is commonly used in medical, industrial and agricultural sciences (Eyduran et al., 2013, Üngüren, 2010). In CHAID analysis, relationships and interactions of independent variables with each other are assessed. If the dependent variable is categoric, then the relationships among the variables are tested with Chisquare test. If the dependent variable is continuous, then the relationships among the variables are tested with F-test (Özer et al., 2016, Kayri and Boysan, 2007). In this study, effects of age, residence place, income, educational level, land size of the producers visiting 2015 and 2017 fairs, their opinions about the prices of fair products, their source of information about the place and time of the fair, significance level of the fairs and the regions from where they participate in fairs on their reasons for participation into fairs were assessed with the aid of CHAID analysis technique.

\section{Results}

\section{Socio-economic Characteristics of the Producers}

The data gathered through questionnaires made with 589 producers participated in the agricultural fairs held in Çanakkale and Tekirdağ provinces are provided in Table 1. Of the participant producers, $6.6 \%$ was at the age of between $20-30$ years, $15.4 \%$ was between $31-40$ years, $22.2 \%$ was between $41-50$ years and $55.7 \%$ was over the age of 50 years (generally aged people). Of the participant producers, $48.9 \%$ was living in villages, $35 \%$ was living in towns and $16.1 \%$ was living in cities. While $21.6 \%$ of the producers participating into agricultural fairs was living in cities in 2015, the ratio decreased almost half to $12.1 \%$ in 2017. About $32 \%$ of the participant producers had an educational level of high school and greater (Table 1).

There are about 3 million agricultural enterprises in Turkey and almost 2 million of them have a land size of less than 50 decares. The average land size of farmers is 61 decares (Anonymous, 2013). Present participants have land sizes greater than the country average. The average land size of the participant producers was 355.4 decares in 2015 and 205 decares in 2015.

Table 1. Socio-economic characteristics of the producers

\begin{tabular}{|c|c|c|c|c|c|c|c|}
\hline & \multirow{3}{*}{ Variables } & \multicolumn{4}{|c|}{ Years } & \multirow{2}{*}{\multicolumn{2}{|c|}{ General }} \\
\hline & & \multicolumn{2}{|c|}{2015} & \multicolumn{2}{|c|}{2017} & & \\
\hline & & $\mathrm{n}$ & $\%$ & $\mathrm{n}$ & $\%$ & $\mathrm{n}$ & $\%$ \\
\hline \multirow{4}{*}{ Age } & 20-30 years & 21 & 8.4 & 18 & 5.3 & 39 & 6.6 \\
\hline & $31-40$ years & 33 & 13.2 & 58 & 17.1 & 91 & 15.4 \\
\hline & $41-50$ years & 67 & 26.8 & 64 & 18.9 & 131 & 22.2 \\
\hline & $50+$ & 129 & 51.6 & 199 & 58.7 & 328 & 55.7 \\
\hline \multirow{3}{*}{ Residence } & Village & 130 & 52 & 158 & 46.6 & 288 & 48.9 \\
\hline & Town & 66 & 26.4 & 140 & 41.3 & 206 & 35 \\
\hline & City & 54 & 21.6 & 41 & 12.1 & 95 & 16.1 \\
\hline \multirow{4}{*}{ Education } & Primary school & 124 & 49.6 & 135 & 39.9 & 259 & 44 \\
\hline & Secondary school & 39 & 15.6 & 98 & 28.9 & 137 & 23.3 \\
\hline & High school & 53 & 21.2 & 76 & 22.4 & 129 & 21.9 \\
\hline & University + & 34 & 13.6 & 30 & 8.8 & 64 & 10.8 \\
\hline \multirow{3}{*}{ Income* } & $2.500-11.000$ euro & 145 & 58 & 147 & 43.4 & 292 & 49.6 \\
\hline & $11.001-50.000$ euro & 95 & 38 & 168 & 49.5 & 263 & 44.7 \\
\hline & +50.000 euro & 10 & 4 & 24 & 7.1 & 34 & 5.7 \\
\hline \multirow{4}{*}{ Land Size } & 10-100 decare & 110 & 44 & 91 & 26.8 & 201 & 34.1 \\
\hline & 101-500 decare & 84 & 33.6 & 197 & 58.2 & 281 & 47.7 \\
\hline & +500 decare & 24 & 9.6 & 50 & 14.7 & 74 & 12.6 \\
\hline & No-land & 32 & 12.8 & 1 & 0,3 & 33 & 5.6 \\
\hline \multirow{4}{*}{$\begin{array}{l}\text { Professional } \\
\text { Experience }\end{array}$} & $1-10$ years & 25 & 10 & 34 & 10 & 59 & 10 \\
\hline & $11-20$ years & 41 & 16.4 & 75 & 22.1 & 116 & 19.7 \\
\hline & 21-30 years & 67 & 26.8 & 56 & 16.5 & 123 & 20.9 \\
\hline & +30 years & 117 & 46.8 & 174 & 51.3 & 291 & 49.4 \\
\hline
\end{tabular}

*Euro, 2017 exchange rate: 1 Euro $=4.11 \mathrm{TL}$ 
Reasons of Producers for Participation into The Fairs

The reasons of producers for participation into the agricultural fairs were different in 2015 and 2017. While half of the producers $(50.4 \%)$ indicated that they visited agricultural fairs just for excursion in 2015 , only $18.3 \%$ indicated that they visited the fairs for excursion. Such a case may be resulted from the location of fairground in the city center in 2015 . The ratio of the participants who visited the fair to look for a special product was $15.6 \%$ in 2016 and $4.7 \%$ in 2017 . The ratio of the producers who will decide on purchase of a product after fair visit was $34 \%$ in 2015 and $9.7 \%$ in 2017 . While the producers participating into the fairs to get information about new technologies and to see them in place constituted majority of the participants $(67 \%)$ in 2015 , there were not any producers visited the fair for this purpose in 2017.

The provinces from where the participants coming were different in both years. While the ratio of the producers from the same province of the fair province was $69.2 \%$ in 2015 , the ratio increased to $81.4 \%$ in 2017 . The ratio of the producers from a different province of the same region was $21.6 \%$ in 2015 and the ratio decreased to $17.1 \%$ in 2017. There were limited international participants of the fairs (Macedonia, Bulgaria). Ratio of these international participants was $0.8 \%$ in 2015 and $1.5 \%$ in 2017. It was observed that almost all of the international participants came to the fairs to purchase a product. About half of the visitors from the other provinces indicated that they intended to buy a product after they visit fair, $10 \%$ indicated that they came to fair to purchase a product, $30 \%$ indicated that they visited the fair to gather information about new technologies and only $10 \%$ indicated that they just came for excursion. The producers coming from abroad and the other provinces with a land size of less than 100 decares indicated that they will purchase a product after visit of the fair and the ones with a land size of greater than 100 decares indicated that they came to fair to purchase the product in their minds (tractor, fertilizer, livestock and so on).

Of the producers living in city center, $33.6 \%$ indicated that they participated into the fair just for excursion, $31.6 \%$ indicated that they came to fair to know about new technologies, $23.2 \%$ indicated that they wish to purchase a product after their visits to fair and $11.6 \%$ indicated that they participated into the fair to get a product they decided before to come to the fair. Of the producers living in villages, $36.8 \%$ indicated their reason to visit as to be informed about the new technologies, $33.5 \%$ as excursion, $17 \%$ as purchase of a product after visit and $9.7 \%$ as to purchase of a product.

The process from the first introduction of new technologies to be known and adoption by large masses accelerated with the contribution of mass media (Cinemre, Demiryürek 2002). It is important to determine the producer source of information about the place and time of the fairs. The most important source of information for agricultural fairs was the mass media $(32 \%)$ to promote participation. Mass media were respectively followed by Leader Farmer Association (24\%), other producers (16.6\%), advisors (agricultural engineers) employed in Agricultural Chambers, Provincial/Town Directorate of Ministry of Agriculture and Forestry (13\%), social media (facebook, twitter etc.) (8.6\%) and adds on motorways
(5.8\%). While Leader Farmer Association and mass media constituted the information sources of producers living in fair provinces, Agricultural Chambers, The Ministry of Agriculture and Forestry and social media constituted the information sources of the producers from the other provinces. Leader Farmer Association $(57.1 \%)$ and mass media $(28.6 \%)$ constituted the primary information sources of international participants. The producers who learned about the fairs through Leader Farmer Association indicated their reasons of visit as to know about new technologies and to reach new information. Agricultural Chambers and Provincial/Town Directorate of Ministry of Agriculture and Forestry constituted the primary information sources of the producers who intent to buy a product from the fairs.

\section{Producer Characteristics Effecting the Reasons for Participation into Agricultural Fairs}

In CHAID analysis conducted to determine the producer characteristics effecting the reasons for participation into agricultural fairs, "participation reasons of producers into agricultural fairs (categoric variable)" were identified as dependent variables. The independent variables effecting dependent variables were considered as; age, residence place, income, educational level, land size of the producers, their opinions on product prices, sources of information about place and time of the fairs, significance level of the fairs and the region from where they participated into fairs.

When the reasons of producers for participation into the fairs were assessed, their source of information about the place and time of the fairs was the most remarkable characteristic. The producers with information source of "mass media" and "the other producers" indicated their reasons for participation into the fairs as excursion $(37.8 \%)$ and saw the new technologies/information (32.2\%). The producers heard about the fairs from producer organizations indicated that they participated into these fairs to purchase a product after their visits to get the product from the fair. The majority of the producers hearing about the place and time of fairs from social media or road-side or posters $(72.9 \%)$ indicated their reasons for participation into the fairs as to see new technologies and to get more information about these technologies. The reasons of producers informed about the place and time of the fairs through Leader Farmer Association were different from the reasons of the producers with the other sources of information about the fairs. The primary reason of the producers heard about the fairs through Leader Farmer Association was to get information about new technologies or to get a new product/technology. Only $20 \%$ of the producers informed through Leader Farmer Association visited fairs just for excursion. The second remarkable characteristics were the land size and the regions from where they participated into the fairs (fair province, international, different province of the same region and different region). The third remarkable factors were their place of residence and level of significance of the fairs.

The producers finding fair products as highly expensive generally indicated that they participated into fairs to see new technologies, they had land sizes of between 101 and 500 decares and they heard about the fairs from mass media or the other producers. Of the producers hearing about the 
fairs from mass media or the other producers and with land sizes of between 101 and 500 decares, $31.5 \%$ indicated that they found fair prices either high or reasonable. These producers mostly indicated their reason to participate into the fairs as to purchase a product from the fairs.

The reasons of participation of the producers heard about the place and time of the fairs from mass media or the other producers differentiated based on their land sizes and place of residence. Of the participants with a source of information as mass media and the other producers, $75 \%$ indicated that they had no land and came to the fair just for excursion. The producers with land sizes of between 10 and 100 decares or greater than 500 decares and residing in villages and towns (generally between 10 and 100 decares land-owners) also indicated their purpose of visit as excursion. However, $60 \%$ of such producers residing in provinces (mostly with a land size of greater than 500 decares) indicated that they will decide on purchase of a product after the visit of the fair or came to fair to purchase of a product. As stated by Rogers (1983), such a finding indicated that the journeys made out of the social systems of the individuals and their large land sizes were commonly used as the indicators of innovativeness. It is defined as relatively earlier acquaintance and adaptation of new ideas and technologies by an individual as compared to the other members of the society (Rogers, 1983).

The reasons of producers heard about the place and time of the fairs from producer organizations (Agricultural Chambers or producer cooperatives) differentiated based on the regions from where they came to fairs. Of the producers coming from the same province, $57.1 \%$ indicated that they came to fair for excursion, $22.9 \%$ indicated that they visited the fair to purchase a product and $20 \%$ indicated that they will decide on purchasing a product after their visit to the fair. Half of the producers participating from out of fair province (from different provinces of the same region or from different regions) indicated that they will decide on purchase of a product after the visit of fair or to purchase the product from the fair.

The reasons of producers learned about the fairs through Leader Farmer Association or informed by the Association were different from the reasons of the producers informed through other sources of information based on their land sizes and regions from where they came (Figure 1). The producers with no-land or land size of less than 100 decares indicated their primary reasons to visit the fairs as to learn about new technologies and to get information about these technologies (39.6\%). Of these producers learned about the fairs through Leader Farmer Association, 22.9\% indicated that they participated into the fairs to purchase a product. Similarly, the ratio of such producers with a land size of greater than 100 decares was $29.6 \%$. Again, in this producer group, the ratio of the producers participated into the fairs to see new technologies and information was $58.5 \%$. Especially the producers leaned about the fair through Leader Farmer Association, with a land size of greater than 100 decares and coming from the fair province or abroad indicated their primary reason of visit as to see and purchase new technologies $(88.2 \%)$.
The reasons of producers for participating into agricultural fairs did not have significant correlations with their ages, educational levels, incomes and significance level of the fairs.

\section{Conclusion}

In agricultural fairs, producers and the companies providing input to agriculture get together at a certain place and a specific time; fairs provide an efficient direct information transfer to producers through demonstrations; offer various acquisitions with regard to both sales and demonstration; offer great promotional tools for producers to gather and search for information about new technologies. It is undeniable that fairs had highly significant effects on acquaintance of agricultural innovations and technologies.

In this study, producer reasons for participation into agricultural fairs were assessed in various different aspects. It can be asserted that producers generally participated into agricultural fairs just for excursion or spend time with their families at weekends. However, statistical analyses revealed that some characteristics or factors of the producers altered their reasons for participation into these fairs and these characteristics had significant effects on their participation reasons.

Both producer organizations (Agricultural Chambers or Cooperatives) and Leader Farmer Association inform producers about the symposiums, seminars and fairs-like activities. In this sense, it was concluded that the producers informed about the agricultural fairs through producer organizations and Leader Farmer Association indicated that they participated into agricultural fairs to purchase a new product or to learn about new technologies/information.

The Leader Farmer Project initiated with the supports of German Agricultural Society improving the efficiency of agriculture in Turkey at the beginning of 1990s resulted in redefinition of some concepts both in the region where the project was implemented and all around the country. Among these concepts, Agricultural Extension is the leading one. Leader Farmer Association have conducted significant activities on training, advice and communication dimensions of Agricultural Extension and present findings also proved remarkable effects of the Association on communication dimension since the producers informed about the fairs through Leader Farmer Association are not just visiting fairs for excursion, but to learn more about and purchase new technologies. Such a case indicated that Leader Farmer Association not only informed producers about the fairs but also conveyed the significance of fairs in acquaintance of new technologies.

When the participation reasons of the producers learned about the fairs through producer organizations or Leader Farmer Association were assessed, it is possible to say that producer organizations played a significant role in orientation of the producers. It was concluded that Leader Farmer Association/producer organizations constituted a significant role to improve existence of individuals in presentation and marketing of products in fairs besides their social life. 


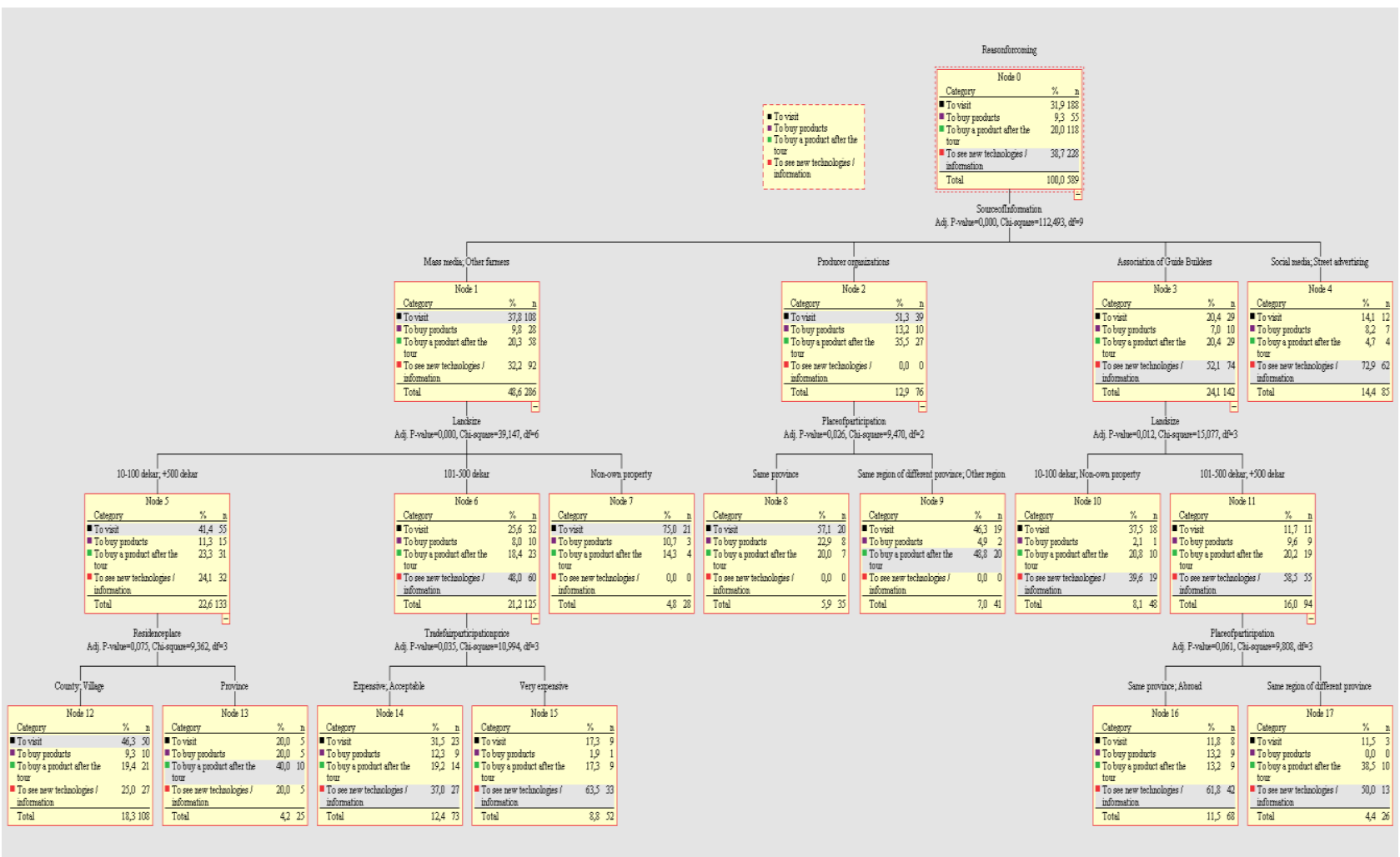

Figure 1. Regression tree for producer reasons of participation into the fairs

Another remarkable outcome of the present study was an innovative issue for the fairs, participation of "large landowning" (more than 500 decares), "cosmopolite" (able to go out the province they live in), "wealthier" (finding fair prices high, but still purchasing) producers into the fairs. These producers are generally the ones deciding on purchase of an item after the visit or directly purchasing pre-determined products from the fairs. This group of producers receive general information about the fairs from mass media or the other producers.

Parallel to global developments, significance of agricultural fairs is increasing in Turkey and agricultural fair organization sector achieved a great progress. It was finally concluded based on present findings that all producers will assign a great significance to fairs and will perceive agricultural fairs as a source of information about new technologies.

\section{References}

Acharya RN, Lillywhite J. 2016. Motivation, Attitude, and Participation in Agricultural Fairs, Agricultural and Applied Economics Association Meeting in Boston, Massachusetts, http://ageconsearch.umn.edu/bitstream/235916/2/Motivation $\% 20$ Satisfaction \%20and\%20Loyalty_Acharya.pdf

Anonymous. 2013. Tarım Arazilerinin Bölünmesinin Önlenmesine Yönelik Yasal Düzenleme Hakkında Düzenleyici Etki Analizi Raporu, GTHB Yayını.

Anonymous. 2017. Türkiye Odalar ve Borsalar Birliği (TOBB) kayıtları ve istatistikleri,

Barros R, de A, Gazola S, Angelis BLD.de. 2016. O perfil dos participantes da $41^{\mathrm{a}}$ exposição feira agropecuária, industrial e comercial de Maringá, Paraná, Brasil, Rosa dos Ventos, Vol.8 (2), 124-135, http://www.ucs.br/etc/revistas/index.php/ rosadosventos/article/view/3399/pdf
Caber M, Güven A, Öztürk A. 2016. Exploring how to match local products fair participation motivations of the visitors and businesses, Journal of Convention \& Event Tourism, Vol 17(3), 220-233. http://www.tandfonline.com/doi/pdf/ 10.1080/15470148.2015.1135092?needAccess=true

Cinemre HA, Demiryürek K. 2002. Tarımsal Yayım ve Haberleşme, Ondokuz Mayıs Üniversitesi Ziraat Fakültesi Ders Kitab1, No:17, Samsun.

Doğan İ. 2003. Holştayn 1rk1 ineklerde süt verimine etki eden faktörlerin CHAID analizi ile incelenmesi, Ankara Üniversitesi Veteriner Fakültesi Dergisi, Sayı 50, Sayfa 6570, 2003.

Dwyer R, Tanner JFJr. 1999. Business marketing: Connecting strategy, relationship, and learning, McGraw-Hill Higher Education.

Eyduran E, Yilmaz M, Tariq MM, Kaygisiz A. 2013. Estimation Of 305-D Milk Yield Using Regression Tree Method In Brown Swiss Cattle, The Journal of Animal \& Plant Sciences, 23(3):731-735

Havlíková M, Kolárová A. 2015. Why Do Agricultural Producers Exhibit at Bread Basket? Agris On-line Papers in Economics and Informatics; Vol 7(4). http://online.agris.cz/ files/2015/agris_on-line_2015_4_havlikova_kolarova.pdf

Ivkov M, Blešić I, Popov Raljić J, Ivkov Džigurski A, Pivac T, Jovanović T. 2015. Visitors' motives for attending a hybrid event: A case study of Agricultural fair, Economics of Agriculture, Volume 62, No. 1.

Kayri M, Boysan M. 2008. Bilişsel Yatkınlık İle Depresyon Düzeyleri İlişkisinin Sınıflandırma ve Regresyon Ağacı İle İncelenmesi, Hacettepe Üniversitesi Eğitim Bilimleri Dergisi, 34: $168-177$

Larsen MH. 2017. Getting a Sense of Agriculture: Visitor Experiences from an Agricultural Fair, Sociologia Ruralis, http://onlinelibrary.wiley.com/journal/10.1111/(ISSN)14679523/earlyview

Mitchell JT. 2005. Conflicting threat perceptions at a rural agricultural fair. Tourism Management, Volume 27, Issue 6, pp. $1298-1307$ 
Özer OO, Yavuz GG, Gül U. 2016. Demografik faktörlerin balık eti tüketimindeki etkisi: Ankara İli örneği, Turkish Journal Of Agriculture - Food Science And Technology, 4(5):356-364.

Rogers EM. 1983. Diffusion of Innovations. Third Edition. The Free Press, New York.

Rosskopf K, Wagner P. 2005. Knowledge Management of Farmers- From Data Generation to Knowledge Sharing, EFITA/WCCA Joint Congress on it in Agriculture, pp. 867874. http://www.informatique-agricole.org/download/efitaconference/Congres_EFITA_2005/PA146\%20$\% 20$ Karin\%20Rosskopf.pdf
Santos JF, Mendonça PB. 2014. Motivations to participate in international trade fairs: The Portuguese experience, British Journal of Economics,Management\&Trade, Vol 4(12), 19571972.

Stricker S, Emmel M, Pape J. 2003. Situation Of Agricultural Information and Communication Technology (ICT) in Germany, EFITA 2003 Conference, Hungary, http://citeseerx.ist.psu.edu/viewdoc/download? doi=10.1.1.3.2789\&rep=rep1\&type $=$ pdf

Üngüren E, Doğan H. 2010. Beş yıldızlı konaklama işletmelerinde çalışanların iş tatmin düzeylerinin Chaid analiz yöntemiyle değerlendirilmesi, C.Ü. İktisadi ve İdari Bilimler Dergisi, Cilt 11, Sayı 2 